\title{
Glottis Verrucous Carcinoma
}

National Cancer Institute

\section{Source}

National Cancer Institute. Glottis Verrucous Carcinoma. NCI Thesaurus. Code C8189.

An exophytic, slow growing, well differentiated and non-metastasizing squamous cell

carcinoma with pushing marg ins that arises from the glottic area of the larynx. It usually presents with hoarseness. 